Theobald Smith Medal to Dr. George Cheever Shattuck, professor emeritus of tropical medicine at Harvard University.

The Charles Franklin Craig Lecture was given by Dr. Albert B. Sabin, research professor of pediatrics, University of Cincinnati Medical School.

\section{Institute of Metals : Medal Awards}

THe Institute of Metals has awarded the following Medals : Institute of Metals (Platinum) Medal, for 1955 , to Dr. C. J. Smithells, director of research of the British Aluminium Co., Ltd., Gerrards Cross, in recognition of his services to metallurgical science, to the metal industries and to the metallurgical profession ; Rosenhain Medal, for 1955, to Dr. W. A. Baker, research manager of the British Non-Ferrous Metals Research Association, London, in recognition of his outstanding contributions to knowledge in the field of physical metallurgy, with special reference to the infiuences of gases and shrinkage on the soundness of cast metals ; W. H. A. Robertson Medal and Premium, for 1954, to Prof. H. Ford and Mr. J. G. Wistreich, for their paper on problems of the control of dimensions, shape and finish in the rolling of sheet and strip and in the drawing of wire $(J$. Inst. Met., $82,281 ; 1954)$.

\section{Polarographic Society: Inaugural Meeting}

THE inaugural meeting of the Polarographic Society was held on November 9 in the Lecture Theatre of the Pharmaceutical Society of Great Britain, 17 Bloomsbury Square, London, W.C.l, with Mr. W. J. Parker in the chair. The meeting was attended by more than forty people interested in the subject, who had come from many parts of Britain. Mr. Parker reviewed the steps leading to the formation of the Society. According to the constitution, the objects of the Society are "to advance and promote the science of polarography in all its aspects and to provide educational facilities in polarography through discussion and any other medium". He said that the Society also hopes to facilitate the discussion of day-to-day problems as well as further an understanding of the basic principles. In referring to the enthusiastic support given to the new Society by the "polarographic profession", Mr. Parker stressed that membership is open to any person interested in the objects of the Society ; the annual subscription has been fixed at $10 \mathrm{~s}$. Four papers were then presented which in themselves epitomized the objects of the Society : they were "A Brief Introduction to Polarography", by Dr. A. L. Glenn, lecturer in pharmaceutical chemistry in the Sehool of Pharmacy, University of London; "The Polarograph with Derivative and Phase Selective Additions", by G. L. Young, Research Department, Cambridge Instrument Co., Ltd. ; "Potential Pitfalls in Practical Polarography", by Mrs. B. Lamb, chief chemist of Tinsley (Industrial Instrumenis), Ltd.; and "The Application of Polarography to Pyrimidine Chemistry", by Mrs. N. Luthy, of Stanford University, Stanford, California (now working at the University of Manchester on a grant from the British Empire Cancer Research Fund). Further information about the Polarographic Society can be obtained from V. S. Griffiths, Chemistry Department, Battersea Polytechnic, London, S.W.11.

\section{Courses in Advanced Technology in Britain}

Following up the statements in Parliament on higher technological education (see p. 22), the Minister of Education, Sir David Eccles, gave in a written answer on December 14 the names of twenty-four technical colleges in which courses in advanced technology had been approved for an increased grant of 75 per cent under Circular 255. Eight of these are in London. The remaining colleges include the Birmingham College of Technology, Bradford Technical College, Cardiff College of Technology and Commerce, Huddersfield Technical College, Leicester College of Technology and Commerce, Manchester College of Technology, Nottingham and District Technical College, Royal Technical College, Salford, and North Staffordshire Technical College, Stoke-onTrent. Ninety technical colleges had applied for this grant; sixty-three had not qualified for it, and three requests are still being considered.

\section{University of Leeds Publications and Theses during $1951-52$}

UNDER the title "Publications and Titles of Theses, 1951-2" (pp. 57; 1954; 6d.) the University of Leeds has issued a pamphlet listing by faculties (and including the Institute of Education, the Department of Adult Education and Extra-mural Studies, and the Library) the publications of which members of the University are authors or joint-authors, and which appeared in print during October 1, 1951September 30, 1952. Titles of theses accepted by the University during the same period for the degrees of master and doctor are similarly listed in an appendix. There is an index of authors. It is proposed to issue similar pamphlets for subsequent academic years.

\section{International Commission on Zoological Nomen- clature: Elections}

THE International Commission on Zoological Nomenclature announces the election of the undermentioned zoologists to be members of the International Commission on Zoological Nomenclature, with effect from the dates stated: K. H. L. Key, principal research officer, Division of Entomology, Commonwealth Scientific and Industrial Research Organization, Canberra, in succession to Joseph Pearson (resigned) (October 15, 1954); Alden H. Miller, professor of zoology and director of the Museum of Vertebrate Zoology, University of California, Berkeley, in succession to J. L. Peters (deceased) (October 29, 1954); Ferdinand Prantl, vice-director, Národni Museum, Prague (October 30, 1954); Wilhelm Kühnelt, professor in the Zoological Institute of the University, Vienna (November $6,1954)$; F. S. Bodenheimer, professor of zoology, Hebrew University, Jerusalem (November 11, 1954); Ernst Mayr, Alexander Agassiz professor of zoology at Harvard College, Cambridge, Mass. (December 4, 1954); Enrico Tortonese, professor of zoology, Istituto e Museo di Zoologia, Universita di Torino, Italy, in succession to Prof. Lodovico di Caporiacco (deceased) (December 16, 1954).

\section{Colonial Service : Recent Appointments}

THE following appointments have recently been made in the Colonial Service: D. J. Billes (senior agricultural officer, Gold Coast), assistant director of agriculture, Gold Coast; I. S. Hutcheson (agricultural officer, Bechuanaland Protectorate), director of agriculture, Bechuanaland Protectorate; E. M. Brown (senior assistant conservator of forests, Jamaica), conservator of forests, Jamaica; I. E. M. Watts (meteorological officer, Singapore), assistant director, 